Covered in: Web of Sciences (WOS); EBSCO; ERIH+; Google Scholar; Index Copernicus; Ideas RePeC; Econpapers; Socionet; CEEOL; Ulrich ProQuest; Cabell, Journalseek; Scipio; Philpapers; SHERPA/RoMEO repositories; KVK; WorldCat; CrossRef; CrossCheck

\section{The Risk of Relapse following \\ Abstinence in Case of Alcohol Abuse Disorder: the Importance of Relational and Normative Support}

\section{Iános-Mátyás-Tamás MIHÓK- GÉCZI1 1 Adrian HATOS²}

${ }^{1}$ PhD Student - University of Oradea, Romania; tamas 269@yahoo.com

${ }^{2} \mathrm{PhD}$, University Professor - University of Oradea, Romania; adrian@hatos.ro; postal address: University of Oradea, Faculty of Social Science, Oradea, str. Universității nr. 1 , Romania
Abstract: The purpose of our article is to contribute to the understanding of the mechanisms that intervene in determining the success of abstinence in case of persons suffering from alcohol use disorder (PAUD), a phenomenon that is poorly investigated, but, obviously, extremely important. Based on the database containing 273 Romanian PAUDs, split in three categories according to their abstinence and relapse status (abstinents without any relapses, abstinents with at least one relapse and ex-abstinents that are active consumers nowadays), we have tested several hypotheses derived from the literature, referring to the factors that influence the risk to relapse. The empirical models have shown, in contradiction with plenty of previous research that underline different correlations with the abstinence's durability, that only two factors have a significant impact on the type of abstinence (with or without relapses): marital status and religion. Our research brings up, this way, the significant importance that the relational and normative context and the social support have in assisting the PAUDs who try to fight their addiction.

Keywords: alcohol use disorder (AUD); abstinence; social support; religiosity;

How to cite: Mihók-Géczi, I.-M.-T., \& Hatos, A. (2019). The Risk of Relapse following Abstinence in Case of Alcohol Abuse Disorder: the Importance of Relational and Normative Support. Postmodern Openings, 10(2), 28-56. doi:10.18662/po/70 



\section{Introduction}

It is difficult to establish the true number of PAUDs in Romania. Existing statistics only cover a part of the phenomenon, since part of the addicts aren't even aware that they are suffering of AUD. A recent Global Status Report on Alcohol and Health of the World Health Organization (World Health Organization, 2014, p. 232) presents for Romania a prevalence of $2 \%$ of alcohol addiction among men but other sources provide numbers up to $10 \%$ which is slightly larger than the one decade ago estimate of $1.5 \%$ (Rehm et al., 2015) .

AUD represents an issue both for individuals and their entourage, but also for society. Individual and social costs of this scourge arise from the effects of AUD upon personal health or upon the health and wellbeing of others, through the risk of accident or violence that it hatches, upon familial cohesion and stability, but also upon the access these families have to economic resources or the access of economic agents to work resources, all aspects underlined by the World Health Organization (2014) as well as by national institutions (Analiza de situatie în România, ocazionată de campania LUNA NATIONAL $\breve{A}$ A INFORMĂRII DESPRE EFECTELE CONSUMULUI DE ALCOOL, 2015).

Abstinence and recovery programs for abstinent PAUDs constitute important directions through which individuals and societies combat excessive alcohol consumption in an organized manner. Unfortunately, the probability of relapse is particularly great and rehabilitation attempts are all too often finalized in failure. Among alcohol addicts that try to overcome their dependency, we believe only $50 \%$ will manage to maintain abstinence while the rest will relapse definitively or episodically $(15 \%)$ before once more attempting abstinence.

These last percentages refer merely to those PAUDs that have followed a recovery program through a specialized clinic, with the aid of long term therapy. This percentage increases to $70.5 \%$ in the case of those who joined later a support group, and respectively diminishes to $45.5 \%$ for those who didn't (Schneider, Lux, \& Lux, 1999, p. 187).

According to the stage in which they find themselves with regards to abstinence, abstinent PAUDs can be: relapsed PAUDs (former abstinent), abstinent PAUDs who suffered one or more relapses along their time of abstinence and abstinent PAUDs (with no relapse). We will be using these categories in our study to determine the subject categories. In our approach the abstinent PAUD is one who refrained from drinking for at least three 
months without any relapses. The abstinent PAUD with relapses is one who refrained from drinking for at least three months without relapse until the moment of the research but who have had relapsed previously. The member of the third category, the relapsed PAUD is an addict who had been an abstinent for at least 6 months - in a row or in episodes - but at the moment of the research was relapsed and has no intention of giving up drinking.

In our research article we attempt to contribute to the research literature dedicated to AUD and the rehabilitation of PAUDs through the multivariate testing of several hypotheses concerning factors which determine the likelihood of success in maintaining abstinence. Our approach will focus on proving the weights the variables of social support in maintaining a long-term abstinence. The article will begin through elaborating the theoretical and empirical hypotheses of the study based on actual research literature. Hypotheses will be tested using bivariate and multivariate tests the latter, through multinomial logistic regressions in blocks, using data from a sample of 273 alcoholics found in one of the three abstinence categories below.

\section{Research theories and results regarding abstinence}

There is no solid evidence-based theory about the resilience of the abstinent PAUD, of his resistance before temptation. In elaborating the hypotheses of this study, we began from a number of directions of theorizing and research that are correlative to the issue of successful abstinence in case of PAUDs. Useful for us, on the one hand, are the psycho-sociological studies regarding AUD and alcohol consumption. Logically we would expect that, at least partially, relapse after abstinence might have the have a similar causality as alcohol consumption. On the other hand, we have drawn inspiration from studies regarding abstinence of addicts but also from documents published by practitioners in the field of abstinence as are those involved in the Alcoholics Anonymous (AA).

A first set of factors identified in the research literature could be grouped in what is called socio-demographic variables, or control variables age and degree of instruction. A second set of factors refers to the social support from which the abstinent benefits, indicated by measures of social integration such as marital status and the number of their children. A special chapter that we can confer to as social and normative support is that of religiosity. 
Plenty of studies associate alcohol consumption with education. The study carried out by Droomers et al. (Droomers, Schrijvers, Stronks, van de Mheen, \& Mackenbach, 1999) emphasizes the fact that excessive alcohol consumption is found more frequently among the lower educated, a result confirmed in other studies as well (Van Oers, Bongers, Van de Goor, \& Garretsen, 1999). Other studies however conclude that the effect of education is inconsistently established (Hill \& Chow, 2002). An explanation for the correlation empirically recorded between the intensity of alcohol consumption and education can be the mediation through profession or occupational status. Some professions have particularly high rates of AUD, and the fact if these correlations are due to certain selection factors or to specific pressure (stress) at the job, remains unclear (Plant, 1978). Mandell et al. (Mandell, Eaton, Anthony, \& Garrison, 1992), conclude that, in the building sector the prevalence of the diagnosis of addiction to alcohol is of 1 in 5, while in the field of transportation, it is of 1 in 6 . According to Hemmingsson et al. (Hemmingsson, Lundberg, Romelsjö, \& Alfredsson, 1997) there exists a powerful relation between the incidence of AUD among different socio-economic groups and professional activity (occupation) and average alcohol consumption among these groups, which means there exists a certain dependency (association) of the occupational status and AUD variables.

Moreover, since, in Romania peculiarly, between villages and urban settlements exists a great difference in what regards educational and professional composition is is highly probable that the manifestations of AUD and of the resistance of abstinent PAUD to be different depending on the type of settlement of residence. It is possible however that these differences might disappear once they are controlled through the variables like level of instruction and/or occupational status.

In the research literature the age, as predictor, benefits of a specific attention, researches indicating a greater susceptibility of the youth for addiction. Some studies analyze the moment in the life-cycle from the perspective of prevalence, while others look at the method of consumption. An important factor in the appearance of addiction is the age of debut of consumption. Addiction is instated at variable pace depending on the age of debut of consumption: from 5-6 years of consumption for a 15-year-old teenager and up to 10-12 years for a person that begins consuming alcohol at the age of approximately 25 years (Schneider et al., 1999). In a longitudinal study, White \& Jackson (2004) followed the changes in consumption along the life-course of the age range of 18-30 years indicating a drop in consumption with the passing of time. Of all those who followed a 
specialized treatment, better results were obtained by older men and married men respectively (Wiens \& Menustik, 1983). Developing on the issue of lifecycle, Barick \& Connors (2002) conclude that relapse and return to alcohol consumption after a time of abstinence could be the, among others, consequence of specific-risky situations in the case of older adults. The results of the study of Dawson et al. (Dawson, Goldstein, \& Grant, 2007) similarly highlight the necessity of a more consistent approach to maintain recovery among abstinent young adults display a particularly great risk of relapse. The studies that investigated the interactions between the predictors of abstinence and relapse are also interesting: an older piece of research quoted by Vaillant (1996) showed that a high level of instruction poses a better protection against relapse than age.

Abandoning alcohol consumption after a long period of abuse is also a learning (or unlearning) process and therefore the length of abstinence and the likelihood of success are auto-correlated. More studies have underlined the fact that the probability of relapse is greater as the period of abstinence is shorter, many sources indicating that 5 years of abstinence would be a critical milestone (Behar, Winokur, \& Berg, 1984). The risk of relapse doesn't cancel out after the crossing of this threshold, however (Dennis, Foss, \& Scott, 2007; Jin, Rourke, Patterson, Taylor, \& Grant, 1998).

At least as interesting and relevant are the studies that relate success in abstinence with social integration and social support, factors of the contexts in which a system of norms and costs-and benefits, incentives and deterrents is imposed, which can limit (or enhance sometimes) alcohol consumption or other harmful behaviours. Half a century ago English sociologist Jock Young (1971), already underlined that social meanings attributed to drug consumption in a certain society or culture have an incontestable importance, the consumer's way of life and the effects derived from his habits being found to be in a tight correlation with the values, norms and expectations of the social environment. Psychologists also insist on the importance of social norms and relations. In The Comprehensive and Sequential Model of the phases of drug consumption, Becoña (1999) mentions that abstinence can be motivated by pressure on behalf of the family, of friends or generally of the society or by problems caused by drug consumption. Similarly, in The model of maturity proposed by Labouvie (1996) the diminishing of alcohol consumption is underlined for the married youth and those who have children.

These references show the importance of a number of factors correlated to social support - such as marital status, the presence or absence of children, the network of friends in encouraging alcohol consumption or, 
on the contrary, abstinence. Thereby, authors such as Booth et al. (Booth, Russell, Soucek, \& Laughlin, 1992) present results that suggest as specific sources (family and friends) and forms (i.e. reinsurance of value) of social support as being important in the recovery of the PAUDs. Temple et al. (Temple, Fillmore, Hartka, Johnstone, Leino, \& Motoyoshi, 1991) conclude that not establishing a marital relationship or returning to the status of celibacy are both associated with an increase in alcohol consumption to elder men, both being situations positively tied to the increase in consumption. It's also been concluded that transition from marriage to divorce has led to a growth in the percentage of men and women classified as excessive alcohol consumers (Bachman, Wadsworth, O'Malley, \& Johnston, 1997).

Another theory elaborated by Oetting and Donnermeyer (1998) The theory of primary socialization - links consumption and abstinence to models of familial socialization. This model considers that behavioural norms, including those about drug consumption, are learned predominantly in the context of interaction with primary socialization sources. Involvement in the family environment - the total number of PAUD's relatives being highlighted as a predictor for alcohol addiction in terms of the evolution of AUD, with the mention that AUD is not necessarily directly hereditary, is the conclusion of authors such as D. Goodwin and Guze (1974), B. Porjesz and Begleiter (1990) respectively R. J. Rose (1998), Drake and Vaillant (1988). Among families in which one member is an PAUD, children are subjected to the risk of developing emotional and behavioural disorders which result in negative results in school, and alongside the emotional disorders and social repercussions, these children may also copy the observed familial model (Hunt, 1997).

We cannot ignore the rationality of the people we are referring to in explaining the success in the recovery of PAUDs either. Health, legal and juridical problems stumbled upon on occasion by these persons could be important motivational factors in joining a recovery program. Such issues can also be deterrent factors in resuming alcohol consumption once the recovery process has begun. For example, in a study focused upon abstinent PAUDs (Tucker, Vuchinich, \& Gladsjo, 1994), recovered subjects have shown (1) greater worries regarding health and a relatively stable work situation in the year preceding initial abstinence, (2) a drop in health related events following the resolution and (3) a drop in law related and total negative events in the three years following resolution.

As such we consider that health problems caused by alcohol consumption constitute a diminishing factor for the risk of relapse. A similar 
hypothesis holds in the case of previous problems with the law, even though some studies suggest an opposite hypothesis, derived from the fact that involvement in deviant behaviours and excessive alcohol consumption are positively correlated through one's inability to control the impulses (Barrick \& Connors, 2002) (Dom, D’haene, Hulstijn, \& Sabbe, 2006).

A factor that intervenes in nearly all studies referring to AUD but particularly in those referring to the success of abstinence programs is religiosity. Although the temptation to justify this fact through the popularity of the AA (Alcoholics Anonymous) initiative exist, in the entire world numerous studies attest the protective role which the intensity of religious faith and practice has in the normative and social support of the abstinent PAUD. Naming a number of studies conducted by Kelly \& Moos (2003), Schaler (1996), Michalak, Trocki \& Bond (2007) or Galanter (2014), the common conclusion is that religiosity is strongly associated with abstinence, and religious people present a lower risk of relapse in accordance to the research literature. Authors such as Tonigan, Miller \& Schermer (2002), Carrico, Gifford \& Moos (2007) or Reith (1999), underline the benefits tied to participating in AA group meetings and the practicing of the 12 steps.

\section{Research Hypotheses}

Relying on the research synthesis and following the objectives of the current research, our hypotheses are the following:

Hyp.1. Abstinence becomes more durable and the risk of relapse lower, with age.

Hyp.2. The risk of relapse is higher in for rural dwellers than it is for the urban residents.

Hyp.3. In the families of abstinent without relapse there are fewer PAUD's relatives (1st-2nd degree), compared to those that have suffered relapse(s) or gave up on abstinence.

Hyp.4. With the increase in educational level chances of relapse or renouncement in abstinents are lower.

Hyp.5. Relapse or renouncement to abstinence is more rarely found among married people.

Hyp.6. Having children increases the probability of maintaining abstinence and diminishes the probability of relapse.

Hyp.7. Health problems increase the chances of maintaining abstinence and avoiding relapse. 
Hyp.8. Higher levels of religiosity are recorded in the case of abstinent PAUD's without relapse compared to those who have suffered relapse(s) or those currently relapsed.

Hyp.9. The length of the period of consumption negatively influences the course of abstinence.

Hyp.10. Legal problems prior to abstinence have an ulterior protective role in maintaining abstinence without relapse.

\section{The Research Strategy}

As stated in the objective and according to the hypotheses, we sought to verify the correlates of belonging to one of the three categories of the dependent variable. In order to reach this objective we have done an expost-facto effect-cause cvasi-experiment. The test of hypotheses above will be made on data from a survey on a convenience sample made up of the three categories of the dependent variable: abstinent PAUDs without relapse, abstinent PAUDs with relapse(s) and currently relapsed abstinent PAUDs (former abstinents).

\subsection{The Study's Variables}

The dependent variable of the study is the state of the abstinent PAUD. The three categories (states) of the dependent variable subjected to examination are:

1) Abstinent PAUD without relapse - who refrained from drinking for at least three months without any relapses

2) Abstinent PAUD with relapse(s) - who refrained from drinking for at least three months without relapse until the moment of the research but who have had relapsed previously at least once

3) Relapsed abstinent PAUD (former abstinent) - an addict who had been an abstinent for at least 6 months - in a row or in episodes - but at the moment of the research was relapsed and has no intention of giving up drinking

\begin{tabular}{|c|c|c|c|c|}
\hline Ivx* & Variable & Measurement & Values & Observations \\
\hline Iv5 & Marital status & Dichotomy & $\begin{array}{l}\text { Marries (1) - Not- } \\
\text { marries (0) }\end{array}$ & $\begin{array}{l}\text { The concubinage } \\
\text { considered } \\
\text { marriage "Yes" }\end{array}$ \\
\hline & & & & $\begin{array}{l}1-56,4 \% \quad / \quad 0- \\
43,6 \%\end{array}$ \\
\hline Iv1 & Age & Numeric & years & Average: 47,64 \\
\hline
\end{tabular}




\begin{tabular}{|c|c|c|c|c|}
\hline Iv6 & Parental status & Dichotomy & $\begin{array}{l}\text { With children }(1)- \\
\text { No children }(0)\end{array}$ & $\begin{array}{l}1-78,8 \% \\
21,2 \%\end{array}$ \\
\hline Iv3 & $\begin{array}{l}\text { Family } \\
\text { antecedents } \\
\text { (Relatives } \\
\text { addicted) }\end{array}$ & Dichotomy & Yes $(1)-$ No $(0)$ & $\begin{array}{l}\text { First and second } \\
\text { degree relatives } \\
\text { considered } \\
1-73,3 \% \quad / \\
26,7 \%\end{array}$ \\
\hline Iv7 & Health issues & Dichotomy & Yes $(1)-\operatorname{No}(0)$ & $\begin{array}{l}1-27,1 \% \\
72,9 \%\end{array}$ \\
\hline Iv8 & Faith/religiosity & Trichotomy & $\begin{array}{l}\text { Yes } \quad(1) \quad- \\
\text { Neutral/neither ys } \\
\text { nor no (2) - No } \\
\text { (3) }\end{array}$ & $\begin{array}{l}1-64,5 \% \\
17,9 \% \\
3-17,6 \%\end{array}$ \\
\hline Iv9 & $\begin{array}{l}\text { Duration of } \\
\text { consumption }\end{array}$ & Numeric & Years & Average: 14,35 \\
\hline Iv2 & $\begin{array}{ll}\text { Type } & \text { of } \\
\text { settlement } & \text { of } \\
\text { residence } & \end{array}$ & Dichotomy & $\begin{array}{l}\text { Urban (1) - Rural } \\
(0)\end{array}$ & $1-74 \% / 0-26 \%$ \\
\hline Iv10 & Legal issues & Dichotomy & Yes $(1)-\operatorname{No}(0)$ & $1-41 \% / 0-59 \%$ \\
\hline Iv4 & Education & Trichotomy & $\begin{array}{l}\text { Primary and lower } \\
\text { secondary (1) - } \\
\text { Upper secondary } \\
(2)-\text { Tertiary (3) }\end{array}$ & $\begin{array}{l}1-28,6 \% \quad / \\
42,1 \% \\
3-29,3 \%\end{array}$ \\
\hline
\end{tabular}

\subsection{The Population of Research}

The studied phenomenon being the abstinence of PAUD, the universe of research is formed by the population of Romanian male PAUDs that have had at least one episode of abstinence, including current abstinents.

\subsection{The Sample. Abstinent categories}

The current study focuses on the analysis of abstinent PAUDs respectively of former abstinents (relapsed PAUDs) from a non-random sample of 273 persons. Of this sample 133 are abstinents without a single relapse (48.7\%), 93 are current abstinents which had at least a relapse(s) $(34.1 \%)$ and 47 are formerly abstinent but currently relapsed. The average age of the people in the sample is that of 47.64 years old.

Data regarding 226 males - abstinent PAUDs who had or did not have relapses - have been collected through interviews conducted in the time period of May 2015 - November 2017 at events that supposed the participation of abstinent PAUDs in various places in North-Western 
Romania, such as: meetings of former patients of Fundația Bonus Pastor's Therapeutic Centre in Ozd, in the county of Mureș; the twentieth anniversary meeting of the first AA group in Cluj-Napoca held in Vâlcele in the county of Cluj; AA groups in Baia Mare, Maramureș and Timișoara; 'The day of open doors' organised by the Nazareth Squadron of the Blue Cross of Romania, in Şura Mică in the county of Sibiu; the post-therapeutic meeting of Bucin in the county of Harghita; the Romanian AA General Service Office meeting and Conference with representatives of AA groups in Romania (both) held at Daness in the county of Mures; the AA National Convention at Baia Mare in the county of Maramureş; Fundaţia Increderea, the Psychiatric and Military Hospitals, the National Anti-drug Agency of Oradea in the county of Bihor.

The people who participated to these events came from different parts of the country as illustrated in the figure $\mathrm{x}$.

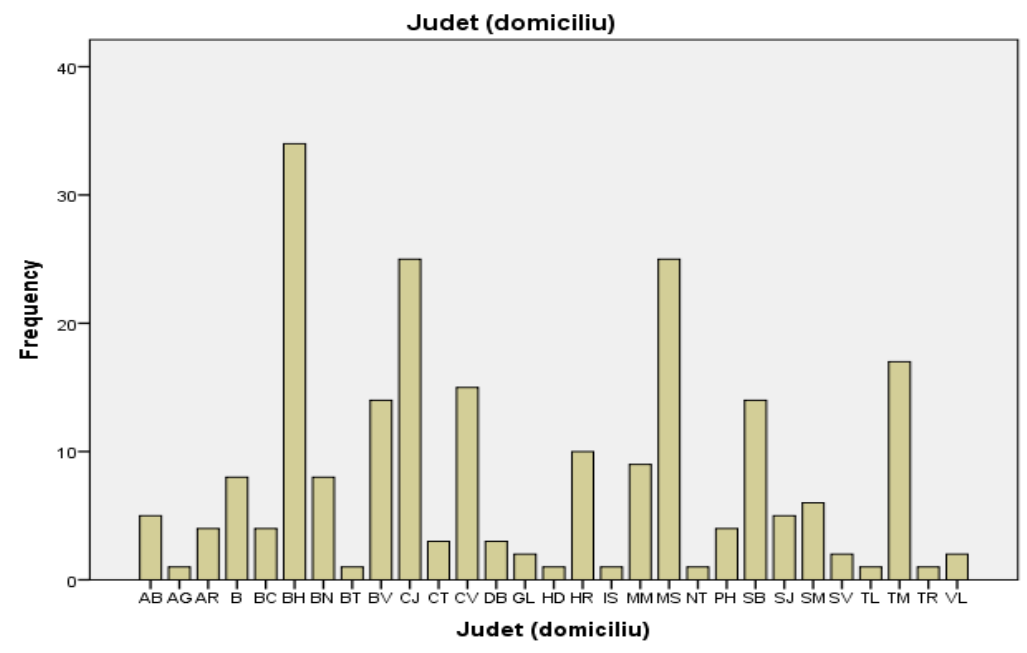

Figure 1. Distribution of abstinence sample to countries of residence

Respondents have been assured of their confidentiality, and as such, the rate of refuse has been low, of about 3\%. The great majority of the questionnaires have been self-completed. Still, following this, $2 \%$ of them have proven to be incomplete and could not be used.

The interviewees have reported periods of abstinence between 3 months and 38 years. At the date of interview all subjects have been abstinent for at least 3 months since their debut or their last relapse. Their ages range between 26 and 80 years (average of 47.88 years). 
Of the 226 abstinents, 133 (58.8\%) are those without relapse. Of the 93 abstinents with relapse $66.7 \%$ have started drinking again before reaching three years of abstinence, this percentage being of $18.3 \%$ in the case of those with over 4.5 years of abstinence. Noteworthy are two extreme cases, one with relapse after 10 years, and another with a relapse following 11.5 years of abstinence.

The situation regarding the number of relapses is presented in Table 2.

Table 2. Abstinents with previous relapses according to the number of relapses

\begin{tabular}{llc} 
Alc. abstinent & N & Percent (\%) \\
\hline One relapse & 38 & 40,9 \\
\hline Two relapses & 17 & 18,3 \\
\hline More than two relapses & 38 & 40,9 \\
\hline Total & 93 & 100
\end{tabular}

A third group of abstinents was composed of 47 male PAUDs, who had in their biographies period(s) of abstinence, however being consumers at the date of the interviewing. These are the relapsed or the former abstinents, who were interviewed between October 2016 / November 2017. Worth mentioning is that identifying and collecting the data from these subjects has been particularly difficult. This is also the reason why $76,6 \%$ of these come from the county of Bihor. In their case the basic selection criteria was acknowledging their status as PAUDs. Also, extremely useful for us in the recruitment process were some of the abstinents of the first lot, who in turn have been acquainted with such people. A part of the interviewed people from this groups have gone through treatment centers, albeit unsuccessfully. The rate of refuse has been higher than in the case of those abstinent, of over $10 \%$.

In this sub-group the age range between 26 and 65 years old (46.49 years on average) and the times of abstinence ranged from 6 months to 4 years and 3 months. Time passed since their last abstinence ranged from 6 months to 9 years. In this category the percentage of people who haven't reached 2 years of abstinence is of $66 \%$; most of them renounced abstinence after 1 year and 6 months (10 people $-21.3 \%$ ).

In Table 3 is presented the declared the frequency of consumption of the relapsed, which concludes that most of them (40.4\%), following the renounce of abstinence, consume alcoholic beverages on a daily basis. On another note, the number of people that had consumed alcohol within the 
last 24 hours (at the time of testing) was 28 people, or a percentage of $59.6 \%$.

Table 3. Frequency of consumption in the relapsed group

\begin{tabular}{lcc} 
Frequency of consumption & $\mathbf{N}$ & $\mathbf{\%}$ \\
\hline Daily & 19 & 40,4 \\
\hline At least 3 times/week & 16 & 34,0 \\
\hline Less than 3 times/week & 3 & 6,4 \\
\hline $\begin{array}{l}\text { Periodically (more than 5 days in a } \\
\text { row) }\end{array}$ & 7 & 14,9 \\
\hline Only at special occasions & 2 & 4,3 \\
\hline
\end{tabular}

\subsection{The Questionnaire}

The data has been collected with the aid of a questionnaire built for revealing certain aspects of social nature regarding the phenomenon of AUD.

The procedure of administration has been established in accordance to the possibilities and conditions at hand, both in groups as well as individually, through face-to-face interviews or through self-completion.

Note: the questionnaire was the working tool, the interview term being used in the case of those questioned personally.

\subsection{The Method of Analysis}

In the first part we proceeded with the bi-varied testing of the hypotheses. Keeping in mind the three categories of the dependent variable and the fact that the independent variables are either categorical or numeric, bivariate tests of the hypotheses have been conducted through either a chisquare tests of association or the one-way ANOV $A$ method.

In the second stage we tested the hypotheses, controlling the independent variables by using the multinomial logical regression method to identify the direct and eventually spurious effects.

\section{Results}

\subsection{The bi-variate tests of the hypotheses}

The results obtained following the tests through the chi-square test of the hypotheses involving categorical independent variables are synthesized in Table 4. In Table 5 we present the results of the ANOVA tests corresponding to the hypotheses referring to age and length of consumption. 
The Risk of Relapse following Abstinence in Case of Alcohol Abuse Disorder: ... Iános-Mátyás-Tamás MIHÓK-GÉCZI \& Adrian HATOS

Table 4. Test of hypotheses through two-way tests of association

\begin{tabular}{|c|c|c|c|c|c|c|c|c|}
\hline \multirow{2}{*}{$\begin{array}{l}\text { Hy } \\
\text { p. }\end{array}$} & & & \multicolumn{4}{|c|}{ Relapse } & \multirow[t]{2}{*}{$\chi^{2}$} & \multirow{2}{*}{$\begin{array}{c}\text { Asymp.Si } \\
\text { g. (2- } \\
\text { sided) }\end{array}$} \\
\hline & & & $\begin{array}{l}\text { Witho } \\
\text { ut } \\
\text { relapse }\end{array}$ & $\begin{array}{l}\text { With } \\
\text { relaps } \\
\mathrm{e}\end{array}$ & $\begin{array}{l}\text { Current } \\
\text { ly } \\
\text { relapse } \\
\text { d }\end{array}$ & $\begin{array}{c}\text { Tot } \\
\text { al }\end{array}$ & & \\
\hline \multirow[t]{2}{*}{1} & \multirow[t]{2}{*}{ Married } & No & 51 & 40 & 28 & 119 & \multirow[b]{2}{*}{6,384} & \multirow[b]{2}{*}{0,041} \\
\hline & & Yes & 82 & 53 & 19 & 154 & & \\
\hline \multirow[t]{2}{*}{3} & \multirow[t]{2}{*}{ Children } & $\mathrm{No}$ & 34 & 14 & 10 & 58 & \multirow[b]{2}{*}{3,613} & \multirow[b]{2}{*}{0,164} \\
\hline & & Yes & 99 & 79 & 37 & 215 & & \\
\hline \multirow[t]{2}{*}{4} & \multirow{2}{*}{$\begin{array}{l}\text { Relative } \\
\text { s addict }\end{array}$} & $\mathrm{No}$ & 41 & 21 & 11 & 73 & \multirow[b]{2}{*}{2,222} & \multirow[b]{2}{*}{0,329} \\
\hline & & Yes & 92 & 72 & 36 & 200 & & \\
\hline \multirow[t]{2}{*}{5} & \multirow{2}{*}{$\begin{array}{l}\text { Health } \\
\text { issues }\end{array}$} & $\mathrm{No}$ & 99 & 66 & 34 & 199 & \multirow[b]{2}{*}{0,342} & \multirow[b]{2}{*}{0,843} \\
\hline & & Yes & 34 & 27 & 13 & 74 & & \\
\hline \multirow{3}{*}{6} & \multirow{3}{*}{$\begin{array}{l}\text { Religiosi } \\
\text { ty }\end{array}$} & Yes & 108 & 64 & 4 & 176 & \multirow{3}{*}{$\begin{array}{c}114,77 \\
2\end{array}$} & \multirow{3}{*}{0,000} \\
\hline & & $\begin{array}{l}\text { Neutral/ } \\
\text { DK }\end{array}$ & 20 & 18 & 11 & 49 & & \\
\hline & & No & 5 & 11 & 32 & 48 & & \\
\hline \multirow[t]{2}{*}{8} & \multirow{2}{*}{$\begin{array}{l}\text { Type of } \\
\text { residenc } \\
\mathrm{e}\end{array}$} & Rural & 41 & 15 & 15 & 71 & \multirow[b]{2}{*}{7,174} & \multirow[b]{2}{*}{0,028} \\
\hline & & Urban & 92 & 78 & 32 & 194 & & \\
\hline \multirow[t]{2}{*}{9} & \multirow{2}{*}{$\begin{array}{l}\text { Legal } \\
\text { issues }\end{array}$} & $\mathrm{No}$ & 81 & 56 & 24 & 161 & \multirow[b]{2}{*}{1,479} & \multirow[b]{2}{*}{0,477} \\
\hline & & Yes & 52 & 37 & 23 & 112 & & \\
\hline \multirow[t]{3}{*}{10} & \multirow{3}{*}{$\begin{array}{l}\text { Educati } \\
\text { on }\end{array}$} & $\begin{array}{l}\text { Primary } \\
\text { and lower } \\
\text { secondary }\end{array}$ & 33 & 22 & 23 & 78 & \multirow[t]{3}{*}{12,324} & 0,015 \\
\hline & & $\begin{array}{l}\text { Upper } \\
\text { secondary }\end{array}$ & 61 & 42 & 12 & 115 & & \\
\hline & & Tertiary & 39 & 29 & 12 & 80 & & \\
\hline
\end{tabular}

Table 5. Results of ANOVA tests

\begin{tabular}{|c|c|c|c|c|c|c|}
\hline \multirow[b]{2}{*}{ Нyp. } & & \multicolumn{3}{|c|}{ Relapse } & \multicolumn{2}{|c|}{ ANOVA } \\
\hline & & $\begin{array}{l}\text { Without } \\
\text { relapse }\end{array}$ & $\begin{array}{l}\text { With } \\
\text { relapse }\end{array}$ & $\begin{array}{l}\text { Currently } \\
\text { relapsed }\end{array}$ & $\mathrm{F}$ & Sig. \\
\hline 2 & Age & 48,76 & 46,62 & 46,49 & 1,848 & 0,159 \\
\hline 7 & $\begin{array}{l}\text { Duration of } \\
\text { consumption }\end{array}$ & 14,80 & 14,35 & 13,06 & 0,930 & 0,396 \\
\hline
\end{tabular}

Following the bivariate tests of the hypotheses we have reached several results. For example, the relapse of an abstinent PAUD or giving up abstinence is associated with being married or not $\left(\chi^{2}=6.384 ; d f=2 ; p=0.041\right)$. Results have indicated the increased presence of the married in the ranks of 
those without relapse. The type of residence is also a characteristic by which PAUDs are differentiated between the three categories $\left(\chi^{2}=7.174 ; d f=2\right.$; $p=0.028)$. Results indicated a higher presence of abstinence without relapse (Annex 1) in urban settings. According to the results, the three analyzed categories are also differentiated from the perspective of degree of education $\left(\chi^{2}=12.324 ; d f=4 ; p=0.015\right)$. Contrary to what was assumed, namely that a higher level of schooling would reduce the odds of relapse, results indicated that most of the abstinents without relapse have completed only the uppersecondary cycle studies (Table 6).

Tables 6. Association tables

Table 6a. marriage * f(Relapse $)$

\begin{tabular}{|c|c|c|c|c|c|c|}
\hline & & & \multicolumn{3}{|c|}{ f(Relapse) } & \multirow[t]{2}{*}{ Total } \\
\hline & & & Without relapse & With relapse(s) & $\begin{array}{c}\text { Relapsed } \\
\text { abst. PAUD }\end{array}$ & \\
\hline \multirow{4}{*}{ marriage } & \multirow{2}{*}{ Yes } & Count & 51 & 40 & 28 & 119 \\
\hline & & \% within f(Relapse) & $38,3 \%$ & $43,0 \%$ & $59,6 \%$ & $43,6 \%$ \\
\hline & \multirow{2}{*}{ No } & Count & 82 & 53 & 19 & 154 \\
\hline & & $\%$ within $\mathrm{f}$ (Relapse) & $61,7 \%$ & $57,0 \%$ & $40,4 \%$ & $56,4 \%$ \\
\hline \multirow{2}{*}{ Total } & & Count & 133 & 93 & 47 & 273 \\
\hline & & \% within $\mathrm{f}($ Relapse $)$ & $100,0 \%$ & $100,0 \%$ & $100,0 \%$ & $100,0 \%$ \\
\hline
\end{tabular}

Table 6b. children * f(Relapse)

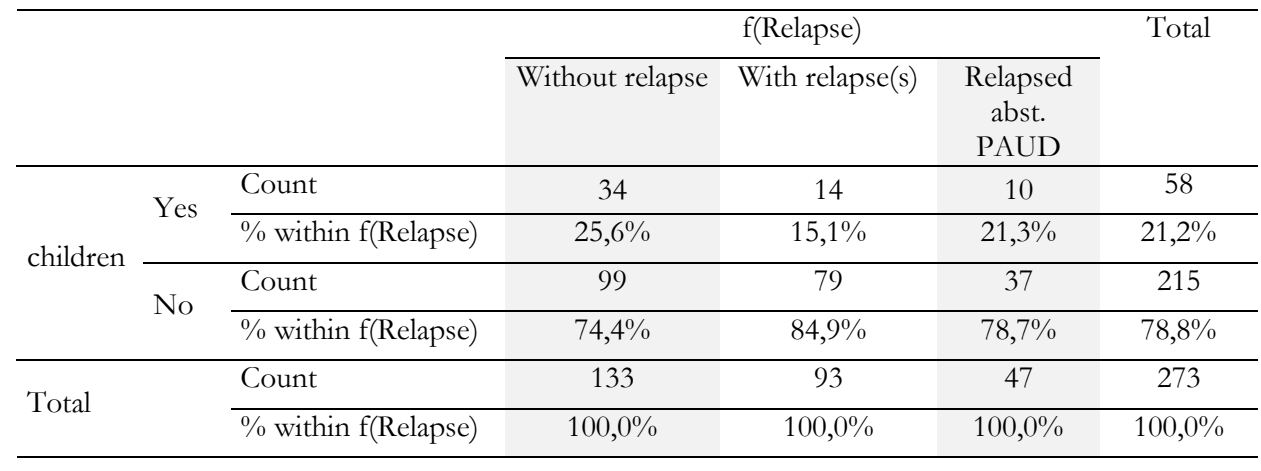

Table 6c. Relatives * f(Relapse)

\begin{tabular}{|c|c|c|c|c|c|c|}
\hline & & & & $\mathrm{f}($ Relapse) & & Total \\
\hline & & & Without relapse & With relapse(s) & $\begin{array}{l}\text { Relapsed } \\
\text { abst. } \\
\text { PAUD }\end{array}$ & \\
\hline & Without & Count & 41 & 21 & 11 & 73 \\
\hline & precedent & & $30,8 \%$ & $22,6 \%$ & $23,4 \%$ & $26,7 \%$ \\
\hline
\end{tabular}


The Risk of Relapse following Abstinence in Case of Alcohol Abuse Disorder: ... Iános-Mátyás-Tamás MIHÓK-GÉCZI \& Adrian HATOS

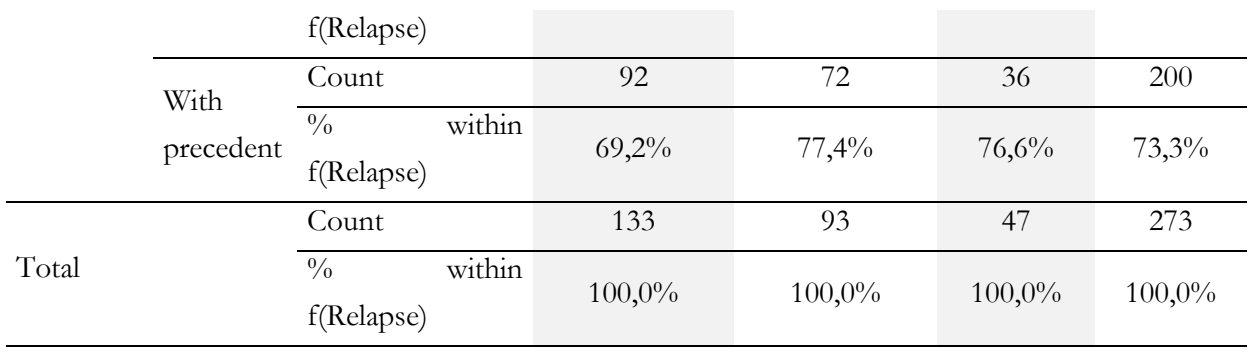

Table 6d. health * f(Relapse $)$

\begin{tabular}{|c|c|c|c|c|c|c|}
\hline & & & \multicolumn{3}{|c|}{ f(Relapse) } & \multirow[t]{2}{*}{ Total } \\
\hline & & & Without relapse & With relapse(s) & $\begin{array}{c}\text { Relapsed } \\
\text { abst. } \\
\text { PAUD }\end{array}$ & \\
\hline \multirow{4}{*}{ health } & \multirow{2}{*}{ No } & Count & 99 & 66 & 34 & 199 \\
\hline & & \% within $\mathrm{f}$ (Relapse) & $74,4 \%$ & $71,0 \%$ & $72,3 \%$ & $72,9 \%$ \\
\hline & \multirow{2}{*}{ Yes } & Count & 34 & 27 & 13 & 74 \\
\hline & & \% within $\mathrm{f}$ (Relapse) & $25,6 \%$ & $29,0 \%$ & $27,7 \%$ & $27,1 \%$ \\
\hline \multirow{2}{*}{ Total } & & Count & 133 & 93 & 47 & 273 \\
\hline & & \% within $\mathrm{f}$ (Relapse) & $100,0 \%$ & $100,0 \%$ & $100,0 \%$ & $100,0 \%$ \\
\hline
\end{tabular}

Table 6e. Faith * f(Relapse)

\begin{tabular}{|c|c|c|c|c|c|c|}
\hline & \multicolumn{3}{|c|}{$\mathrm{f}$ (Relapse) } & \multirow[t]{2}{*}{ Total } \\
\hline & & & Without relapse & With relapse(s) & $\begin{array}{c}\text { Relapsed } \\
\text { abst. } \\
\text { PAUD }\end{array}$ & \\
\hline \multirow{6}{*}{ Faith } & \multirow{2}{*}{ Yes } & Count & 108 & 64 & 4 & 176 \\
\hline & & \% within $\mathrm{f}$ (Relapse) & $81,2 \%$ & $68,8 \%$ & $8,5 \%$ & $64,5 \%$ \\
\hline & \multirow{2}{*}{$\mathrm{N} / \mathrm{A}$} & Count & 20 & 18 & 11 & 49 \\
\hline & & \% within $\mathrm{f}$ (Relapse) & $15,0 \%$ & $19,4 \%$ & $23,4 \%$ & $17,9 \%$ \\
\hline & \multirow{2}{*}{ No } & Count & 5 & 11 & 32 & 48 \\
\hline & & \% within $\mathrm{f}$ (Relapse) & $3,8 \%$ & $11,8 \%$ & $68,1 \%$ & $17,6 \%$ \\
\hline \multirow{2}{*}{ Total } & & Count & 133 & 93 & 47 & 273 \\
\hline & & \% within $\mathrm{f}$ (Relapse) & $100,0 \%$ & $100,0 \%$ & $100,0 \%$ & $100,0 \%$ \\
\hline
\end{tabular}

Table 6f. Environment $*$ f(Relapse $)$

\begin{tabular}{|c|c|c|c|c|}
\hline & \multicolumn{3}{|c|}{ f(Relapse) } & \multirow[t]{2}{*}{ Total } \\
\hline & Without relapse & With relapse(s) & $\begin{array}{c}\text { Relapsed } \\
\text { abst. } \\
\text { PAUD }\end{array}$ & \\
\hline Environment rural Count & 41 & 15 & 15 & 71 \\
\hline
\end{tabular}




\begin{tabular}{|c|c|c|c|c|c|c|c|}
\hline & & $\begin{array}{l}\% \\
\mathrm{f}(\text { Relapse })\end{array}$ & within & $30,8 \%$ & $16,1 \%$ & $31,9 \%$ & $26,0 \%$ \\
\hline & \multirow[b]{2}{*}{ urban } & Count & & 92 & 78 & 32 & 202 \\
\hline & & $\begin{array}{l}\text { \% } \\
\mathrm{f}(\text { Relapse) }\end{array}$ & within & $69,2 \%$ & $83,9 \%$ & $68,1 \%$ & $74,0 \%$ \\
\hline \multirow[b]{2}{*}{ Total } & & Count & & 133 & 93 & 47 & 273 \\
\hline & & $\begin{array}{l}\% \\
\text { f(Relapse) }\end{array}$ & within & $100,0 \%$ & $100,0 \%$ & $100,0 \%$ & $100,0 \%$ \\
\hline
\end{tabular}

Table 6g. law * f(Relapse $)$

\begin{tabular}{|c|c|c|c|c|c|c|}
\hline & \multicolumn{3}{|c|}{ f(Relapse) } & \multirow[t]{2}{*}{ Total } \\
\hline & & & Without relapse & With relapse(s) & $\begin{array}{c}\text { Relapsed } \\
\text { abst. } \\
\text { PAUD }\end{array}$ & \\
\hline \multirow{4}{*}{ law } & \multirow{2}{*}{ No } & Count & 81 & 56 & 24 & 161 \\
\hline & & $\%$ within f(Relapse) & $60,9 \%$ & $60,2 \%$ & $51,1 \%$ & $59,0 \%$ \\
\hline & \multirow{2}{*}{ Yes } & Count & 52 & 37 & 23 & 112 \\
\hline & & $\%$ within $\mathrm{f}$ (Relapse) & $39,1 \%$ & $39,8 \%$ & $48,9 \%$ & $41,0 \%$ \\
\hline \multirow{2}{*}{ Total } & & Count & 133 & 93 & 47 & 273 \\
\hline & & $\%$ within $\mathrm{f}$ (Relapse) & $100,0 \%$ & $100,0 \%$ & $100,0 \%$ & $100,0 \%$ \\
\hline
\end{tabular}

Table 6h. Education * f(Relapse)

\begin{tabular}{|c|c|c|c|c|c|c|}
\hline & & & \multicolumn{3}{|c|}{ f(Relapse) } & \multirow[t]{2}{*}{ Total } \\
\hline & & & $\begin{array}{l}\text { Without } \\
\text { relapse }\end{array}$ & With relapse(s) & $\begin{array}{l}\text { Relapsed } \\
\text { abst. } \\
\text { PAUD }\end{array}$ & \\
\hline \multirow{6}{*}{ Education } & \multirow[b]{2}{*}{ midschool } & Count & 33 & 22 & 23 & 78 \\
\hline & & $\begin{array}{l}\% \\
\mathrm{f} \text { (Relapse) }\end{array}$ & $24,8 \%$ & $23,7 \%$ & $48,9 \%$ & $28,6 \%$ \\
\hline & \multirow[b]{2}{*}{ highschool } & Count & 61 & 42 & 12 & 115 \\
\hline & & $\begin{array}{l}\% \% \text { within } \\
\text { f(Relapse) }\end{array}$ & $45,9 \%$ & $45,2 \%$ & $25,5 \%$ & $42,1 \%$ \\
\hline & \multirow[b]{2}{*}{ college } & Count & 39 & 29 & 12 & 80 \\
\hline & & $\begin{array}{l}\% \\
\mathrm{f} \text { (Relapse) }\end{array}$ & $29,3 \%$ & $31,2 \%$ & $25,5 \%$ & $29,3 \%$ \\
\hline \multirow[b]{2}{*}{ Total } & & Count & 133 & 93 & 47 & 273 \\
\hline & & $\begin{array}{l}\% \% \text { within } \\
\text { f(Relapse) }\end{array}$ & $100,0 \%$ & $100,0 \%$ & $100,0 \%$ & $100,0 \%$ \\
\hline
\end{tabular}


Age does not constitute a differentiating criterion between the three categories of the dependent variable: the differences (in average values of age) being statistically insignificant $(p=0.159)$.

The hypothesis regarding parental status has not been confirmed either since the results $(\phi=0.164)$ indicated that parental status (in this case paternal) does not reduce the risk of an eventual relapse or renouncing of abstinence. Similarly, the presence in the family of 1 st and 2nd degree relatives with similar problems (PAUD), eventual health or legal problems, the length of the period of consumption did not appeared as having any effect in maintaining abstinence through these bi-variate tests.

The bypothesis regarding the impact of religiosity has been confirmed, however, $\left(\chi^{2}=114.772 ; d f=4 ; \quad p=0.000\right)$. Results indicate a significant association between the status of abstinent/abstinent with relapse(s)/relapsed and the position towards faith. Abstinents without relapse are those who have reported most faith compared to those abstinent who have suffered relapse(s) or those currently relapsed. $81.2 \%$ of those without relapse attest that faith definitely helped them in attaining and later maintaining abstinence. At the opposite can be found those currently relapsed who have proven to manifest the least amount of faith (Table 6).

All these relations must be verified in while controlling the effect of the other independent variables in order to check for covariates and spurious relationships. I have conducted this testing through a multinomial logistical regression.

\subsection{Modelling through multinomial logistic regression}

The dependent variable is the same as in the previous case: type of alcoholic, with the three categories: abstinent alcoholic without relapse, abstinent alcoholic with relapse(s) and relapsed abstinent alcoholic (former abstinent).

In the multinomial logistic regression, the predictor variables, have been grouped in three distinct blocks and successively introduced in the modelling: variables;

I. age, type of residence and familial antecedents; i.e. social-structural

II. level of education, parental status and marital status;

III. length of the period of consumption, religiosity, health problems, legal problems.

For this regression, the length of period of consumption and age variables have each been coded in three categories: 1) less than 10 years; 2) 
between 10 and 20 years and 3) over 20 years and respectively 1) under 40 years, 2) 41-55 years and 3) over 55 years.

The possible multicollinearity the independent variables has been tested and the results of the testing have not indicated such a problem.

\subsection{The results of the multinomial logistical regression}

The reference category of the models of logistical regression has been that of currently relapsed PAUDs. Values of the multiple correlation illustrated in Table 7, indicate a moderate prediction, values being situated far under 1 even in block III where they have the highest values.

Table 7. Estimates of multiple correlation (Pseudo R-square)

\begin{tabular}{lll}
\multirow{2}{*}{ I } & Cox and Snell & 0,072 \\
\cline { 2 - 3 } & Nagelkerke & 0,083 \\
\cline { 2 - 3 } & McFadden & 0,037 \\
\hline \multirow{2}{*}{ II } & Cox and Snell & 0,149 \\
\cline { 2 - 3 } & Nagelkerke & 0,171 \\
\cline { 2 - 3 } & McFadden & 0,079 \\
\hline \multirow{2}{*}{ III } & Cox and Snell & 0,409 \\
\cline { 2 - 3 } & Nagelkerke & 0,470 \\
\cline { 2 - 3 } & McFadden & 0,258
\end{tabular}

The diagnosis values of above indicate the fact that introducing every block of variables significantly increases the predictive capacity of the model.

\subsection{Interpretation of parameters}

From the „Parameter Estimates” tables (presented in Tables 8a, 8b and $8 \mathrm{c}$ ) in the case of the first block - where we look upon predictors for the dependent variable categories without relapse and with relapse(s) compared to the relapsed - we highlight the coefficient of regression $b=$ 0.961 in case of those with relapse(s) for category 0 (rural) of the variable of type of residence (med), with a $p=0.026$. The chance of being an abstinent alcoholic with relapses compared to those currently relapsed is significantly smaller $(\operatorname{Exp}(B)=0.382)$ in the case of subjects from a rural settlements. 
The Risk of Relapse following Abstinence in Case of Alcohol Abuse Disorder: ... Iános-Mátyás-Tamás MIHÓK-GÉCZI \& Adrian HATOS

\section{Tables 8. Logistic multinomial regression}

Tables 8a. Model 1. Logistic multinomial regression (the dependent variable: abstinent PAUD type,; reference category: relapsed)

\begin{tabular}{|c|c|c|c|c|c|c|c|}
\hline & & B & $\begin{array}{l}\text { Std. } \\
\text { Error }\end{array}$ & Wald & df & Sig. & $\operatorname{Exp}(B)$ \\
\hline \multirow{8}{*}{$\begin{array}{l}\text { Without } \\
\text { relapse }\end{array}$} & Intercept & 1,419 & ,417 & 11,561 & 1 & ,001 & \\
\hline & $\begin{array}{l}\text { Age3 }=\text { less than } \\
40\end{array}$ &,- 444 &, 538 & 679 & 1 & ,410 & ,642 \\
\hline & $\begin{array}{l}\text { Age } 3=\text { between } \\
41 \text { and } 55\end{array}$ &,- 720 &, 450 & 2,557 & 1 & ,110 & ,487 \\
\hline & Age3 $=$ over 55 & $0^{\mathrm{b}}$ & . & . & 0 & . & . \\
\hline & environment: rural & ,041 & ,377 & ,012 & 1 & ,914 & 1,042 \\
\hline & $\begin{array}{l}\text { environment: } \\
\text { urban }\end{array}$ & $0^{\mathrm{b}}$ & . & . & 0 & . & . \\
\hline & $\begin{array}{l}\text { relatives }=\text { without } \\
\text { precedent }\end{array}$ & , 400 & ,402 & ,988 & 1 & ,320 & 1,491 \\
\hline & $\begin{array}{l}\text { relatives }=\text { with } \\
\text { precedent }\end{array}$ & $0^{\mathrm{b}}$ & . & . & 0 & . & . \\
\hline \multirow{8}{*}{$\begin{array}{c}\text { With } \\
\text { relapse(s) }\end{array}$} & Intercept & ,626 &, 479 & 1,707 & 1 & ,191 & \\
\hline & $\begin{array}{l}\text { Age3 }=\text { less than } \\
40\end{array}$ &, 555 & ,601 & ,854 & 1 & ,355 & 1,742 \\
\hline & $\begin{array}{l}\text { Age } 3=\text { between } \\
41 \text { and } 55\end{array}$ & ,326 &, 513 & , 402 & 1 &, 526 & 1,385 \\
\hline & Age $3=$ over 55 & $0^{\mathrm{b}}$ & . & . & 0 & . & . \\
\hline & environment: rural &,- 961 &, 431 & 4,981 & 1 & ,026 & ,382 \\
\hline & $\begin{array}{l}\text { environment: } \\
\text { urban }\end{array}$ & $0^{\mathrm{b}}$ & . & . & 0 & . & . \\
\hline & $\begin{array}{l}\text { relatives }=\text { without } \\
\text { precedent }\end{array}$ &,- 209 &, 434 & ,232 & 1 & ,630 & 812 \\
\hline & $\begin{array}{l}\text { relatives }=\text { with } \\
\text { precedent }\end{array}$ & $0^{\mathrm{b}}$ & . & . & 0 & . & . \\
\hline
\end{tabular}

\begin{tabular}{|l|l|}
\hline Cox and Snell & 0,072 \\
\hline Nagelkerke & 0,083 \\
\hline McFadden & 0,037 \\
\hline
\end{tabular}

Tables 8b. Model 2. Logistic multinomial regression (the dependent variable: abstinent PAUD type, reference category: relapsed)

\begin{tabular}{|c|l|c|c|c|c|c|c|}
\hline \multicolumn{2}{|c|}{} & B & $\begin{array}{c}\text { Std. } \\
\text { Error }\end{array}$ & Wald & df & Sig. & Exp(B) \\
\hline \multirow{3}{*}{$\begin{array}{c}\text { Without } \\
\text { relapse }\end{array}$} & Intercept & 1,599 &, 501 & 10,197 & 1 &, 001 & \\
\cline { 2 - 8 } & Age3 = less than 40 &,- 397 &, 605 &, 431 & 1 &, 511 &, 672 \\
\cline { 2 - 8 } & $\begin{array}{l}\text { Age3 = between 41 } \\
\text { and 55 }\end{array}$ &,- 658 &, 468 & 1,980 & 1 &, 159 &, 518 \\
\cline { 2 - 8 } & Age3 = over 55 & 0 b &. &. & 0 &. &. \\
\hline
\end{tabular}




\begin{tabular}{|c|c|c|c|c|c|c|c|}
\hline & environment: rural & ,308 & 423 &, 530 & 1 & 466 & 1,360 \\
\hline & environment: urban & $0^{\mathrm{b}}$ & r & . & 0 & . & . \\
\hline & $\begin{array}{l}\text { relatives }=\text { without } \\
\text { precedent }\end{array}$ &, 570 & ,423 & 1,812 & 1 & ,178 & 1,768 \\
\hline & $\begin{array}{l}\text { relatives }=\text { with } \\
\text { precedent }\end{array}$ & $0^{\mathrm{b}}$ & . & . & 0 & . & \\
\hline & $\begin{array}{l}\text { education } \\
\text { midschool }\end{array}$ &,- 770 & ,483 & 2,540 & 1 & 111 & ,463 \\
\hline & $\begin{array}{ll}\text { education } & = \\
\text { highschool } & \end{array}$ & ,637 & ,484 & 1,733 & 1 & ,188 & 1,891 \\
\hline & education $=$ college & $0^{\mathrm{b}}$ & . & . & 0 & . & \\
\hline & children $=$ no &, 756 &, 495 & 2,331 & 1 & ,127 & 2,129 \\
\hline & children $=$ yes & $0^{\mathrm{b}}$ & . & . & 0 & . & \\
\hline & marriage $=$ no &,- 976 & ,387 & 6,373 & 1 & ,012 & ,377 \\
\hline & marriage $=$ yes & $0^{\mathrm{b}}$ & & . & 0 & . & . \\
\hline \multirow{15}{*}{$\begin{array}{c}\text { With } \\
\text { relapse(s) }\end{array}$} & Intercept & 842 &, 552 & 2,324 & 1 & 127 & \\
\hline & Age $3=$ less than 40 & ,945 & ,659 & 2,058 & 1 &, 151 & 2,573 \\
\hline & $\begin{array}{l}\text { Age } 3=\text { between } 41 \\
\text { and } 55\end{array}$ &, 401 &, 525 &, 583 & 1 & ,445 & 1,493 \\
\hline & Age $3=$ over 55 & $0^{\mathrm{b}}$ & . & . & 0 & . & \\
\hline & environment: rural &,- 724 & ,468 & 2,391 & 1 &, 122 & 485 \\
\hline & environment: urban & $0^{\mathrm{b}}$ & . & . & 0 & . & . \\
\hline & $\begin{array}{l}\text { relatives }=\text { without } \\
\text { precedent }\end{array}$ &,- 025 & ,449 & ,003 & 1 & ,956 & ,975 \\
\hline & $\begin{array}{l}\text { relatives } \\
\text { precedent }\end{array}$ & $0^{\mathrm{b}}$ & . & . & 0 & . & \\
\hline & $\begin{array}{l}\text { education } \\
\text { midschool }\end{array}$ &,- 647 & ,504 & 1,649 & 1 & 199 & ,523 \\
\hline & $\begin{array}{ll}\text { education } & = \\
\text { highschool } & \end{array}$ &, 464 & ,496 & ,874 & 1 & ,350 & 1,590 \\
\hline & education $=$ college & $0^{\mathrm{b}}$ & . & . & 0 & . & \\
\hline & children $=$ no &,- 250 &, 537 & 217 & 1 & ,641 &, 778 \\
\hline & children $=$ yes & $0^{\mathrm{b}}$ & . & . & 0 & . & . \\
\hline & marriage $=$ no &,- 660 & ,399 & 2,735 & 1 & ,098 & ,517 \\
\hline & marriage $=$ yes & $0^{\mathrm{b}}$ & . & . & 0 & . & 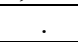 \\
\hline
\end{tabular}

\begin{tabular}{|l|l|}
\hline Cox and Snell & 0,149 \\
\hline Nagelkerke & 0,171 \\
\hline McFadden & 0,079 \\
\hline
\end{tabular}

Tables 8c. Model 3. Logistic multinomial regression (the dependent variable: abstinent PAUD type; reference category: relapsed)

\begin{tabular}{|c|l|c|c|c|c|c|c|}
\hline \multicolumn{2}{|c|}{} & B & $\begin{array}{c}\text { Std. } \\
\text { Error }\end{array}$ & Wald & df & Sig. & Exp(B) \\
\hline \multirow{2}{*}{$\begin{array}{c}\text { Without } \\
\text { relapse }\end{array}$} & Intercept & $-2,376$ & 1,084 & 4,801 & 1 &, 028 & \\
\cline { 2 - 8 } & Age3 = less than 40 &, 126 &, 940 &, 018 & 1 &, 893 & 1,134 \\
\cline { 2 - 8 } & $\begin{array}{l}\text { Age3 = between 41 } \\
\text { and 55 }\end{array}$ &, 140 &, 652 &, 046 & 1 &, 830 & 1,151 \\
\hline
\end{tabular}


The Risk of Relapse following Abstinence in Case of Alcohol Abuse Disorder: ... Iános-Mátyás-Tamás MIHÓK-GÉCZI \& Adrian HATOS

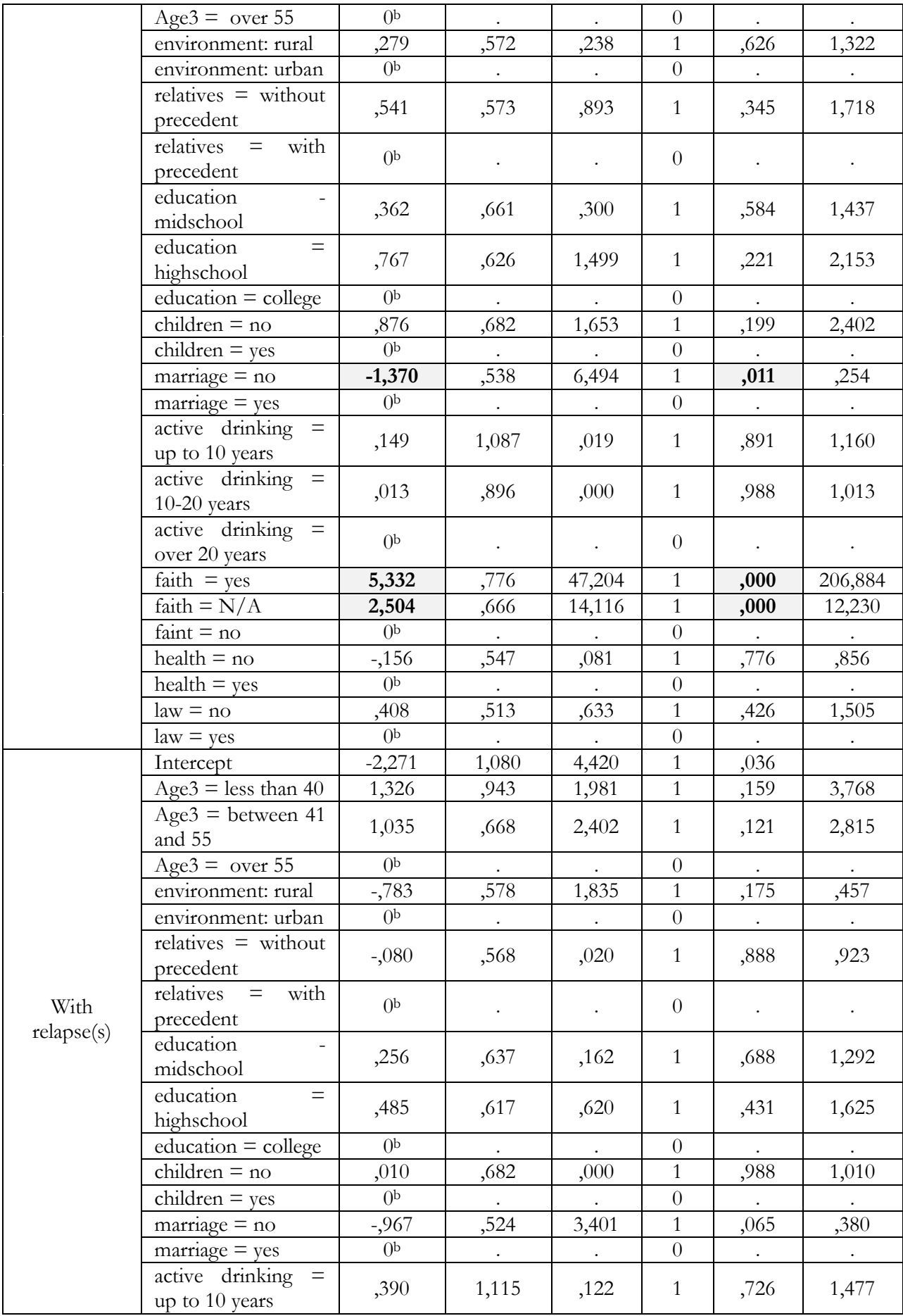




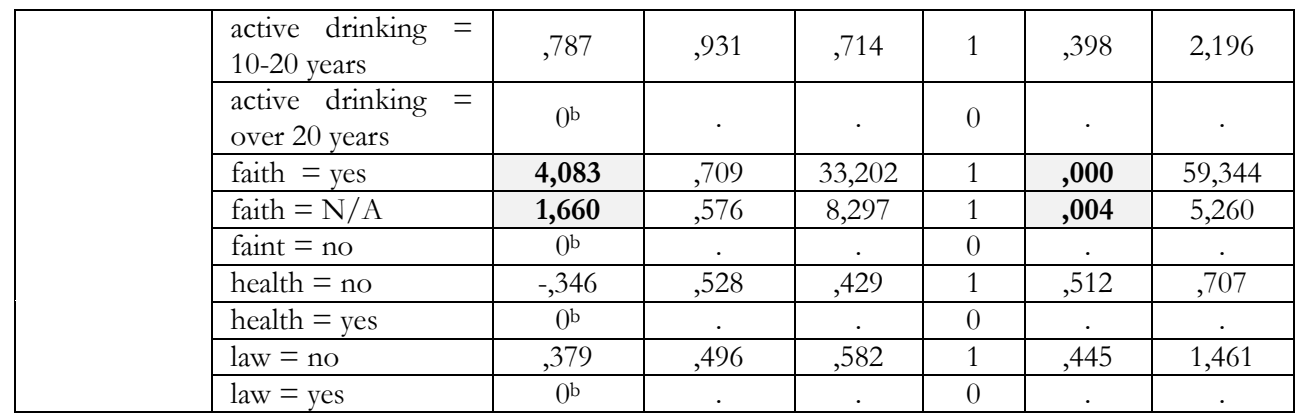

\begin{tabular}{|l|l|}
\hline Cox and Snell & 0,409 \\
\hline Nagelkerke & 0,470 \\
\hline McFadden & 0,258 \\
\hline
\end{tabular}

This effect - of the type of residence - vanishes once we introduce the second block. In this case, however, due to an effect of marital status: unmarried subject have a significantly smaller probability (three times smaller $-\operatorname{Exp}(B)=0.377)$ of belonging to the category of Abstinents without Relapse compared to Relapsed Abstinents. A similar effect, albeit much weaker $(p=0,098)$ is the homologous model which compared abstinents with relapses with those currently relapsed. In other words, the risk of relapse is higher for unmarried PAUDs.

The most significant effects are recorded in the regression equations that contain the third block of independent variables. While the effect previously described of marital status remains significant, the impact of religiosity is particularly strong: the probability of declaring one's self as Religious or Neutral in report with religion is from 5 to 200 times higher in the people belonging to the categories of abstinent without relapse and abstinent with relapse, compared to relapsed people. The risk of relapse is, therefore, smaller among those who declare themselves religious.

\subsection{Discussing the results}

The majority of hypotheses formulated in the opening of the chapter are rejected in our analyses, only three variables have a significant effect upon the distribution of the dependent variable in the of logistic regression. The negative relation between the rural environment and the success of abstinence is spurious being the result of marginal associations with one of the variables introduced in the second block, most likely education. The same thing can be said about the significant bi-variate association with the level of instruction which disappears in the multivariate regression. In other 
words we have serious clues that associations between types of abstinence with the type of residence and education reflect in fact the complex interactions between marital status and the level of instruction and the failure or success of abstinence suggesting a causal mechanism in which an important place has the motivation of status preservation.

Marital status therefore appears as an indicator for some important characteristics for the success of attempted abstinence. The probability of remaining abstinent without relapse in the case of those that are married grows over 2.65 times compared to the category of the relapsed. The homologous probability increase is of nearly 4 in the model with all the blocks of variables while the chance of being an abstinent with former relapses reported to that of being a relapsed abstinent would be 2.65 times greater in the third model of regression $(\mathrm{p}=0.065)$.

As a predictor, of the ten independent variables, the one proving to best differentiate the abstinent PAUDs of different categories has been the declared religiosity (Tables 8c). Both in the case of those who have affirmed "definitely yes" or "more likely yes" at the question of whether faith helped in gaining/maintaining abstinence (coded with 1 - item A14 questionnaire), as well as in those indecisive who have answered with "neither yes, nor no" (coded with 2) the chances of being currently relapsed are significantly smaller than being in the other two categories of the dependent variable.

These results are all the more eloquent if we look at the highest percentage of those who believed that faith was not involved in attaining the status of abstinent. These are the relapsed, of which $68.1 \%$ have had this opinion. Also, here we mention, for the sake of comparison, that this opinion has been shared by only $3.8 \%$ of those without relapse, respectively $11.8 \%$ of those who had relapse(s).

The research literature is rich in articles that study the connection between abstinence and faith. Some of those considered the most relevant have been mentioned in the analysis of literature. Therefore, these results are not surprising at all, being in concordance with those mentioned in the specialty literature.

The fact that, from a relatively long list of predictors, a significant statistical effect on the odds of success of abstinence is only of marital status and religiosity is particularly important for explanations of the phenomenon of addiction but also for the models of intervention in the support of addicts. Both characteristics attest the positive impact of social relations, on the one hand, while religiosity underlines as well the effect of normativity. It must be specified that most of the times when religiosity is invoked in the context of this research, this is strongly correlated with the participation in 
support groups such as Alcoholics Anonymous. In other words religiosity indicates indirectly, also the effectiveness of social support. According to the analyses above, the only crucial factors for the determining the chances of success in abstinence for the PAUD are the existence of effective social bonds, capable of imposing a peculiar behaviour through sanctions and rewards, the preservation of their effect being synergistically multiplied by an adequate motivational or normative context.

\section{Conclusions}

In this article we intended to test several hypotheses deducted from the research literature referring to the chances of recovery of abstinent PAUD. Having at hand a sample of 273 male abstinent PAUDs divided in three categories reflecting different grates of success in maintaining abstinence - without relapse, with past relapses and currently relapsed - we have elaborated bivariate tests and multivariate models (multinomial logistic regressions) of belonging to one of the three classes of abstinents.

The most important conclusion of our analyses is that the probability of relapse of abstinent PAUDs is decisively determined by the social and normative support in which the attempt at abstinence is conducted. The positive impact of marital status and religiosity, effects that cancels even the significant associations of the dependent variable with the type of residence and the level of education, indicate the fact that in the rehabilitation of PAUDs are critical the existence of social connections capable of contributing to maintaining abstinence, aspect conjoined with the effective adhesion to a normative system capable of motivationally supporting the effort of abstinence.

The majority of predictors included in the multinomial logistic regression models have proven to have a statistically non-significant effect upon the distribution of the dependent variable. Age, the presence of relatives with antecedents of AUD, parental status (the presence of children), length of period of consumption or former health problems and legal incidents regarding alcohol abuse do not seem to influence the difficulty with which abstinent PAUDs maintain their abstinence. It is important to underline that these variables do not even present significant bivariate associations with the dependent variable.

According to the present study, the fact of being married offers security in the case of an eventual relapse. Abstinents without relapse are differentiated from the other studied categories through the fact they are more likely to be married. Most probable that civil state explains as well the 
bi-varied relations between the type of residence and the level of instruction, and the dependent variable through motivational mechanisms related to the relational pressure but also by the need to status preservation.

Many AUD treatment programs have religious foundations, faith being considered a strong support in gaining and maintaining abstinence. Within the present study we have concluded that religiosity differentiates the abstinent PAUDs without relapse and that with relapse(s) from the relapsed ones also as a predictor in multivariate models. People with high levels of self-reported faith have five times greater odds of maintaining abstinence, without relapsing. According to the final model of the present study, referring to the chances of a continuous abstinence without relapse, abstinent PAUD subjects who declare themselves to be faithful and married have the highest chances of success.

\section{The limits of the study}

One of the limits of the present study is the fact that the study's participants only men. Assuming the identity of PAUD, be it even abstinent, is a delicate matter, more so in the case of females. As male authors, earning the trust and conducting the interviews has been easier, therefore facilitating a greater sample of participants. As additional proof stands the low rate of refusals.

At the same time, the relatively small number of the sample of relapsed individuals presents another limit that will be improved, hopefully, in the future. This fact is due to the delayed initiation of the data collection, since initially we had in sight only the currently abstinents with or without past relapses.

Religiosity as a variable raises the problem of endogeneity, this being measured post, or following the abstinence (in all cases: without relapse, with relapse, or returning to consumption). In the present case it was not possible to conduct a longitudinal analysis, and the risk of possible errors in endogeneity, has to be admitted.

We also see as a limit in the fact that a part of those who had an abstinence shorter than 6 months (10 people) have been interviewed in a protected environment in specialty centers, partaking in longer duration recovery programs, 3 to 9 months.

Another limitation of the present study could be considered the fact that the majority of addicts interviewed have gone through a treatment program, and the data collection as we mentioned has been concluded mostly at events in which such people have participated. There are however 
abstinent PAUDs who have succeeded through their own will, successfully, to renounce alcohol, but identifying these people is a particularly difficult task. In the final database we find five such people. These make up a selection bias which is possible to have influenced the results in inflating the effect of religiosity. Despite this precaution we believe that our results indicate a significant positive effect of interventions that combine the supportive social dimension with the spiritual one.

Alas, our study has all the limitations that a transversal investigation incubates in the condition of certain phenomena carried out over the course of time, in pretty long time intervals which affects the consistency of measuring the dependent variable. Therefore, there is a probability that current abstinents might relapse, as well as those relapsed to give up on consumption once more, even if all of them are firm in maintaining their current behaviour. Obviously a more longitudinal engagement of the biographies of alcohol consumers, using the event-history analysis methodology would produce stronger results.

\section{References}

Analiza de situație in România, ocażionată de campania LUNA NAṬIONAL $\breve{A} A$

INFORM ARII DESPRE EFECTELE CONSUMULUI DE ALCOOL. (2015). Retrieved from http://insp.gov.ro/sites/cnepss/wpcontent/uploads/2016/01/ANALIZA-DE-SITUATIE-ALCOOL2015.pdf

Bachman, J. G., Wadsworth, K. N., O'Malley, P. M., \& Johnston, L. D. (1997). Smoking, drinking, and drug use in young adulthood: The impacts of new freedoms and new responsibilities. Hillsdale, NJ, US: Lawrence Erlbaum Associates, Inc.

Barrick, C., \& Connors, G. J. (2002). Relapse prevention and maintaining abstinence in older adults with alcohol-use disorders. Drugs \& aging, 19(8), 583-594.

Becoña, E. (1999). Bases teóricas que sustentan los programas de prevención de drogas. Madrid: Plan Nacional sobre Drogas.

Behar, D., Winokur, G., \& Berg, C. J. (1984). Depression in the abstinent alcoholic. The American journal of psychiatry, 141(9), 1105-7. doi:10.1176/ajp.141.9.1105

Booth, B. M., Russell, D. W., Soucek, S., \& Laughlin, P. R. (1992). Social support and outcome of alcoholism treatment: An exploratory analysis. The American journal of drug and alcohol abuse, 18(1), 87-101.

Carrico, A. W., Gifford, E. V., \& Moos, R. H. (2007). Spirituality/religiosity promotes acceptance-based responding and 12-step involvement. Drug and alcohol dependence, 89(1), 66-73. 
The Risk of Relapse following Abstinence in Case of Alcohol Abuse Disorder: ... Iános-Mátyás-Tamás MIHÓK-GÉCZI \& Adrian HATOS

Dawson, D. A., Goldstein, R. B., \& Grant, B. F. (2007). Rates and correlates of relapse among individuals in remission from DSM-IV alcohol dependence: A 3-year follow-up. Alcoholism: Clinical and Experimental Research, 31(12), 2036-2045.

Dennis, M. L., Foss, M. A., \& Scott, C. K. (2007). An eight-year perspective on the relationship between the duration of abstinence and other aspects of recovery. Evaluation Review, 31(6), 585-612.

Dom, G., D’haene, P., Hulstijn, W., \& Sabbe, B. (2006). Impulsivity in abstinent early-and late-onset alcoholics: differences in self-report measures and a discounting task. Addiction, 101(1), 50-59.

Drake, R. E., \& Vaillant, G. E. (1988). Predicting Alcoholism and Personality Disorder in a 33-year Longitudinal Study of Children of Alcoholics. Addiction, 83(7), 799-807.

Droomers, M., Schrijvers, C. T., Stronks, K., van de Mheen, D., \& Mackenbach, J. P. (1999). Educational differences in excessive alcohol consumption: the role of psychosocial and material stressors. Preventive medicine, 29(1), 1-10.

Galanter, M. (2014). Understanding Alcoholics Anonymous as a Spiritual Fellowship: From Individual to Social Structure. Alcoholism Treatment Quarterly, 32(2-3), 111-119.

Goodwin, D. W., \& Guze, S. B. (1974). Heredity and alcoholism The biology of alcoholism (pp. 37-52). Germany: Springer.

Hemmingsson, T., Lundberg, I., Romelsjö, A., \& Alfredsson, L. (1997). Alcoholism in social classes and occupations in Sweden. International Journal of Epidemiology, 26(3), 584-591.

Hill, E. M., \& Chow, K. (2002). Life-history theory and risky drinking. Addiction, 97(4), 401-413.

Hunt, M. E. (1997). A comparison of family of origin factors between children of alcoholics and children of non-alcoholics in a longitudinal panel. The American journal of drug and alcobol abuse, 23(4), 597-613.

Jin, H., Rourke, S. B., Patterson, T. L., Taylor, M. J., \& Grant, I. (1998). Predictors of relapse in long-term abstinent alcoholics. Journal of Studies on Alcohol, 59(6), 640-646.

Kelly, J. F., \& Moos, R. (2003). Dropout from 12-step self-help groups: Prevalence, predictors, and counteracting treatment influences. Journal of Substance Abuse Treatment, 24(3), 241-250.

Labouvie, E. (1996). Maturing out of substance use: Selection and self-correction. Journal of Drug Issues, 26(2), 457-476.

Mandell, W., Eaton, W. W., Anthony, J. C., \& Garrison, R. (1992). Alcoholism and occupations: a review and analysis of 104 occupations. Alcoholism: Clinical and Experimental Research, 16(4), 734-746. 
Michalak, L., Trocki, K., \& Bond, J. (2007). Religion and alcohol in the US National Alcohol Survey: how important is religion for abstention and drinking? Drug \& Alcobol Dependence, 87(2), 268-280.

Oetting, E. R., \& Donnermeyer, J. F. (1998). Primary socialization theory: The etiology of drug use and deviance. I. Substance use \& misuse, 33(4), 995-1026.

Plant, M. A. (1978). Occupation and alcoholism: cause or effect? A controlled study of recruits to the drink trade. Substance Use \& Misuse, 13(4), 605-626.

Porjesz, B., \& Begleiter, H. (1990). Event-related potentials in individuals at risk for alcoholism. Alcohol, 7(5), 465-469.

Rehm, J., Anderson, P., Barry, J., Dimitrov, P., Elekes, Z., Feijão, F., . . Kraus, L. (2015). Prevalence of and potential influencing factors for alcohol dependence in Europe. European Addiction Research, 21(1), 6-18.

Reith, G. (1999). In search of lost time: Recall, projection and the phenomenology of addiction. Time \& Society, 8(1), 99-117.

Rose, R. J. (1998). A developmental behavior-genetic perspective on alcoholism risk. Alcohol Health Res World, 22(2), 131-143.

Schaler, J. A. (1996). Spiritual thinking in addiction-treatment providers: The Spiritual Belief Scale (SBS). Alcoholism Treatment Quarterly, 14(3), 7-33.

Schneider, R., Lux, I., \& Lux, H. (1999). Alcoolul și medicamentele - droguri? Sibiu: Hora.

Temple, M. T., Fillmore, K. M., Hartka, E., Johnstone, B., Leino, E. V., \& Motoyoshi, M. (1991). A meta-analysis of change in marital and employment status as predictors of alcohol consumption on a typical occasion. Addiction, 86(10), 1269-1281.

Tonigan, J. S., Miller, W. R., \& Schermer, C. (2002). Atheists, agnostics and Alcoholics Anonymous. Journal of studies on alcohol, 63(5), 534-541.

Tucker, J. A., Vuchinich, R. E., \& Gladsjo, J. A. (1994). Environmental events surrounding natural recovery from alcohol-related problems. Addictions Nursing, 6(4), 117-128.

World Health Organization. (2014). Global status report on alcohol and health (924156475X). Retrieved from https://www.who.int/substance abuse/publications/alcohol 2014/en/

Vaillant, G. E. (1996). A long-term follow-up of male alcohol abuse. Archives of General Psychiatry, 53(3), 243-249.

Van Oers, J., Bongers, I., Van de Goor, L., \& Garretsen, H. (1999). Alcohol consumption, alcohol-related problems, problem drinking, and socioeconomic status. Alcohol and alcoholism (Oxford, Oxfordshire), 34(1), 7888.

White, H. R., \& Jackson, K. (2004). Social and psychological influences on emerging adult drinking behavior. Alcohol Research \& Health, 28(4), 182-190. 
The Risk of Relapse following Abstinence in Case of Alcohol Abuse Disorder: ... Iános-Mátyás-Tamás MIHÓK-GÉCZI \& Adrian HATOS

Wiens, A. N., \& Menustik, C. E. (1983). Treatment outcome and patient characteristics in an aversion therapy program for alcoholism. American Psychologist, 38(10), 1089.

Young, J. (1971). The drugtakers: The social meaning of drug use. London, UK:

MacGibbon and Kee. 